Chirurgia (2021) 116: 609-619

No. 5, September - October

Copyright $\odot$ Celsius

http://dx.doi.org/10.21614/chirurgia.116.5.609

\title{
An Unexpected High Rate of Internal Hernia in Our OAGB Experience as Revisional Surgery for Morbid Obesity
}

\author{
Francesco Di Capua, Matteo Uccelli, Giovanni Carlo Cesana, Alberto Oldani, Stefano OImi \\ General and Oncologic Surgery Department, Centre of Bariatric Surgery, San Marco Hospital GSD, Zingonia (BG), Italy
}

*Corresponding author:

Francesco Di Capua, MD

Resident in General Surgery

(University of Milan, via Francesco

Sforza 35, 20122 Milan, Italy)

General and Oncologic Surgery

Department - Centre of Bariatric

Surgery, San Marco Hospital GSD

Corso Europa, 7 - 24040 - Zingonia

$(\mathrm{BG})$, Italy

E-mail: francesco.dicapua@unimi.it

Abbreviations:

IH - internal hernia,

LRYGB - laparoscopic roux-en-y gastric

bypass,

OAGB - one anastomosis gastric bypass,

GERD - Gastro-esophageal Reflux

Disease,

IFSO - Federation for Surgery of Obesity

and Metabolic Disorders,

SBO - small bowel obstruction,

POD - postoperative day.

Received: 25.05.2021

Accepted: 28.07.2021

\section{Rezumat}

O rată neașteptată de apariție a herniilor interne în urma reviziilor chirurgicale bariatrice de tipul OAGB pentru obezitatea morbidă

Introducere: Hernia internă (HI) este o complicație recunoscută a bypass-ului gastric pe ansă în Y prin abord laparoscopic (BGRYL), cu o incidență care variază de la $0 \%$ la $5 \%$. In bypass-ul gastric cu anastomoză prin abord deschis (OAGB), hernia internă este raportată a fi absentă deoarece acesta nu implică practicarea unei jejuno-jejunostomii, prezentă în BGRYL. Mai multe studii au raportat serii mari de cazuri de pacienți la care s-a efectuat OAGB fără apariția HI prin defectul mezenteric Petersen. În consecință, nu există nicio recomandare pentru închiderea de rutină a defectelor mezenterice în OAGB. Cu toate acestea, începând cu anul 2015, unii autori au început să raporteze această complicație în procedurile OAGB.

Material şi Metode: Studiul analizează retrospectiv 98 de cazuri de OAGB efectuate în instituția noastră din 2014. OAGB a fost practicată secundar gastrectomiei laparoscopice longitudinale (GLL) în 96\% din cazuri. Indicațiile pentru intervenția chirurgicală secundară au fost creşterea ponderală şi/sau o formă severă de boală de reflux gastro-esofagian (BRGE). Rezultatele tuturor procedurilor OAGB au fost colectate la momentul inițial şi la 1, 3, 6, 12 şi 24 de luni.

Rezultate:Rata complicaților (>30 de zile după externare) care au necesitat o nouă intervenție chirurgicală a fost de $21,4 \%$ (21/98). Principalele cauze ale reintervenției au fost persistența unei forme severe de BRGE/Reflux biliar (14/21) şi ocluzia intestinală prin hernie internă (4/21). HI a fost identificată la 4\% dintre pacienți. Concluzie: Hernia internă ar putea fi mai frecventă decât cea 
raportată în literatură. Închiderea defectelor mezenterice în OAGB trebuie efectuată întotdeauna în timpul reviziilor chirurgicale bariatrice pentru HI complicată.

Cuvinte cheie: chirurgie bariatrică, obezitate, OAGB, revizii chirurgicale bariatrice, hernie Petersen, hernie internă

\begin{abstract}
Introduction: Internal hernia ( $\mathrm{IH})$ is a well-known complication of laparoscopic roux-en-y gastric bypass (LRYGB) with a reported incidence that ranges from $0 \%$ to $5 \%$. In one anastomosis gastric bypass (OAGB), internal herniation is reported to be absent due to the lack of a jejuno-jejunostomy, which is present in LRYGB. Several papers reported large case series of patients undergoing OAGB with no IH through Petersen mesenteric defect. Consequently, there is no recommendation for routine closure of the mesenteric defects in OAGB. However, starting from 2015, some authors started reporting this complication in OAGB procedures.

Material and Methods: The outcomes of 98 cases of revisional OAGB performed at our institution from 2014 were retrospectively collected. OAGB was secondary surgery following laparoscopic Sleeve Gastrectomy (LSG) in $96 \%$ of patients. The indications for secondary surgery were weight regain and/or severe Gastro-esophageal Reflux Disease (GERD). Outcomes of all OAGB procedures were collected at baseline and at 1, 3, 6, 12 and 24 months.

Results: The rate of complications (>30 days after discharge) requiring new surgery was $21.4 \%$ (21/98). The main causes of reintervention were the persistence of severe GERD/Biliary Reflux (14/21) and bowel obstruction due to Internal Hernia (4/21). IH was found in 4\% of patients.

Conclusion: Internal Hernia could be more common than reported in literature. The closure of mesenteric defects in OAGB should always be performed during revisional surgery for complicated IH.
\end{abstract}

Key words: bariatric surgery, obesity, OAGB, revisional bariatric surgery, Petersen hernia, internal hernia

\section{Introduction}

One Anastomosis Gastric Bypass (OAGB) is considered a safe and effective alternative to the gold standard laparoscopic roux en $y$ gastric bypass (LRYGB) for treating morbid obesity in a broad range of obese patients according to the latest statement of International Federation for Surgery of Obesity and Metabolic Disorders (IFSO) (1). In recent literature, OAGB is reported to have similar outcomes and lower complication rates compared to LRYGB, moreover it is a less complex surgery and it presents a shorter operative time compared to LRYGB (1). These findings are also confirmed in a recent meta- analysis of Dimitrios et al. where outcomes and complication rates of the two surgeries are compared across sixteen papers (2). However, among late complications, small bowel obstruction (SBO) and subsequent revision surgery are far more common in LRYGB than in OAGB due to the development of Internal Hernia (IH) (1).

IH develops after laparoscopic RYGB due to the presence of mesenteric defects left open. The most frequent sites of internal herniation are the jejuno-jejunostomy mesenteric defect, the mesenteric defect between the transverse mesocolon and Roux-limb mesentery (Petersen's defect) and transverse mesocolon defect in patients with a retrocolic Roux-limb (3). In 
$\mathrm{OAGB}$, the rate of $\mathrm{IH}$ is reported to be inferior compared to LRYGB, probably because there is no jejuno-jejunal anastomosis, which is present in LRYGB $(1,4)$. In LRYGB with antecolic roux limb reconstruction and routine closure of mesenteric defects, the IH rates range between $0-5 \%(4-6)$. In open gastric surgery as in Billroth II reconstruction, the rate of $\mathrm{IH}(0-2 \%)$ is reported to be inferior compared to LRYGB, although all mesenteric defects are left open. This is probably due to the development of more post-operative adhesion after laparotomy, which limits the bowel motility and hence the chance of internal herniation (7-9).

Regarding OAGB, there are only few reports of internal hernia in literature and most papers with large series of OAGB do not report this late complication, hence the incidence of IH is almost zero $(5,10-13)$. For this reason, there is no recommendation to close the mesenteric defects in this type of surgery (1). However, there are more papers reporting IH after OAGB plus few more unpublished cases, suggesting this complication is more common than thought (14-19). These reports not only suggest that OAGB is not a procedure without any risk of internal hernia, but they also open to new questions about the prevention, early diagnosis and the correct management of this complication. In this paper, we report our experience in OAGB surgery as secondary bariatric surgery, describing outcomes and complications.

\section{Materials and Methods}

\section{Study Design}

This retrospective study analyzed data from patients who underwent revisional OAGB procedure from January 2014 to January 2020. All procedures were performed in the same bariatric surgery center. All 98 OAGB procedures considered in this study were secondary bariatric procedures. In our center, the primary surgery for treating morbid obesity is Laparoscopic Sleeve Gastrectomy (LSG), which was also the main primary surgery for patients included in this study (94/98; 96\%). Indications for OAGB revisional surgery in obese patients were the development of severe Gastro-esophageal Reflux Disease (GERD) or weight regain. A Braun anastomosis was regularly performed with OAGB procedure for all patients starting from 2018 to avoid GERD recurrence and biliary reflux. All clinical records of all OAGB patients were examined and outcomes were registered.

\section{Surgical Technique}

Pneumoperitoneum is induced using Veress needle in left subcostal space. Four trocars are then placed: $10 \mathrm{~mm}$ port in the left subcostal space, slightly lateral to emiclavear line (occupied by a 30-degree laparoscope); $5 \mathrm{~mm}$ port in the epigastric space; $5 \mathrm{~mm}$ port in the right flank for the operator's left hand and 15 $\mathrm{mm}$ port in the left periumbilical space for the operator's right hand. A $38 \mathrm{Fr}$ orogastric tube is inserted for calibrating gastric tubulization. The lesser omentum is opened using LigaSure ${ }^{\mathrm{TM}}$ Maryland Jaw (Medtronic, Minneapolis, MN) and gastric tubulization is performed using Signia $^{\text {TM }}$ with Tri-StapleTM technology (Medtronic, Minneapolis, MN), leaving a gastric pouch of at least $12 \mathrm{~cm}$. The Treitz ligament is recognized and a latero-lateral antecolic gastro-jejunal anastomosis is performed $150 \mathrm{~cm}$ from the Treitz ligament using Medtronic Signia Tri-Staple ${ }^{\mathrm{TM}} 45 \mathrm{~mm}$ purple cartridge. A $150 \mathrm{~cm}$ biliopancreatic limb was preferred due to most patients having a BMI $<40 \mathrm{Kg} / \mathrm{m}^{2}$. The anastomotic breach is closed using Medtronic V-Loc ${ }^{\mathrm{TM}}$ 3/0. If necessary, the Braun anastomosis is performed at $50 \mathrm{~cm}$ from the gastro-jejunal anastomosis with Medtronic Signia Tri-Staple ${ }^{\mathrm{TM}}$ $45 \mathrm{~mm}$ brown cartridge to avoid biliary reflux, which is common in OAGB reconstruction.

\section{Postoperative}

On the first postoperative day (POD), patients were mobilized with the aid of nurses and urinary catheter was removed. On the second POD gastro-esophageal X-ray with water- 
soluble oral contrast medium administration was performed and if leakage was ruled out, patients started a liquid diet on the same day. If there is any sign of perforation or leak on the X-ray, or if clinical signs of complications such as fever are present, a CT-scan with water-soluble oral contrast medium administration is performed. Blood tests, including CRP, are performed on first and third PODs. If the postoperative course was uneventful, patients were discharged on the third POD. Low molecular weight heparin was continued for 24 days and PPI (Proton-pump inhibitor) up to 60 days after surgery. Routine follow up is scheduled at 1, 3, 6, 12, 18 and 24 months.

\section{Statistical Analysis}

Descriptive statistics was used to summarize patient baseline characteristics and clinical data (Age, Sex, BMI, previous surgery, comorbidities, outcomes). Continuous variables were expressed as mean \pm standard deviation. Categorical variables were expressed as percentages. Overall reintervention rates between OAGB group and OAGB with Braun anastomosis group was compared using Yates chi-square test. Reintervention rates for GERD/Biliary reflux was compared using Fisher chi-square test. Statistical significance was set at $\mathrm{p}<0.05$.

\section{Results}

\section{Preoperative Data}

Baseline characteristics of all patients are shown in Table 1. Of the 98 patients that underwent OAGB surgery, 16 were males and 82 females. Laparoscopic sleeve gastrectomy was the first procedure in $96 \%$ of patients that underwent OAGB. Preoperative mean BMI was found to be $36 \pm 8 \mathrm{~kg} / \mathrm{m}^{2}$. Mean patient age was $48 \pm 8$ years.

\section{Comorbidities}

Characteristics are summarized in Table 2. Pre-operative Gastroesophageal Reflux Disease
Table 1. Baseline patient characteristics and demographics

\begin{tabular}{ll}
\hline Males (\%) & $16(16.3 \%)$ \\
\hline Females (\%) & $82(83.7 \%)$ \\
\hline Mean Age \pm SD & $48 \pm 8$ \\
\hline Mean BMI \pm SD & $36 \pm 8$ \\
\hline Previous Surgery (cases; \%) & LSG $(94 / 98 ; 96 \%)$ \\
& LAGB $(2 / 98 ; 2 \%)$ \\
LGP $(2 / 98 ; 2 \%)$ \\
\hline This table reports data from patients before the OAGB surgery. \\
SD: Standard Deviation; BMI: Body Mass Index; LSG: laparoscopic Sleeve \\
Gastrectomy; LGP: laparoscopic Gastric plication; LAGB: laparoscopic \\
\end{tabular}

(GERD) and esophagitis were found, respectively, in $17 \%$ and $22.8 \%$ of patients.

\section{Surgery and Postoperative Course}

Table 3 summarizes operative and postoperative variables. OAGB without Braun anastomosis was performed in 51 cases $(52 \%)$, while OAGB with Braun anastomosis was performed in 47 cases (48\%). Initially, Braun anastomosis was performed only in selected patients with morbid obesity and GERD. Starting from 2018, OAGB with Braun anastomosis was regularly performed in all patients to avoid the development/ persistence of GERD and biliary reflux symptoms in obese patients. A regular perioperative course with no complications was recorded in $94.9 \%$ of the patients (93/98 patients). Complications during hospitalization and $<30$ days after discharge were stratified according to the Clavien-Dindo classification as follows:

- Grade I: 1/98 (1.02\%). One postoperative blood loss without the requirement of blood transfusion.

Table 2. Comorbidities

\begin{tabular}{ll}
\hline GERD (\%) & $20(20.4 \%)$ \\
\hline Esophagitis (\%) & Grade A 11 (11.2\%) \\
& Grade B 6 (6.1\%) \\
& Grade C $5(5.1 \%)$ \\
& Barrett's esophagus 2 (2\%) \\
\hline Hiatus Hernia (\%) & $21(21.4 \%)$ \\
\hline Diabetes Mellitus (\%) & $7(7.1 \%)$ \\
\hline Arterial Hypertension (\%) & $14(14.3 \%)$ \\
\hline OSAS (\%) & $7(7.1 \%)$ \\
\hline This table reports data from patients before the OAGB surgery. \\
GERD: Gastro-Esophageal Reflux Disease; \\
OSAS: Obstructive Sleep Apnea Syndrome
\end{tabular}


Table 3. Revisional OAGB surgery outcomes

\begin{tabular}{|c|c|}
\hline Mean Follow-Up (Months) & $27 \pm 13$ \\
\hline${ }^{1}$ Mean BMI \pm SD & $27 \pm 11.7$ \\
\hline $\begin{array}{l}{ }^{1} \text { Mean \%EBMIL } \\
\text { (patients with starting BMl>35 kg/m²) }\end{array}$ & $52 \pm 30$ \\
\hline Operative Time in Minutes \pm SD & $53 \pm 25$ \\
\hline Type of OAGB (\%) & $\begin{array}{l}\text { Without Braun anastomosis } \\
51 / 98(52 \%) \\
\text { With Braun anastomosis } \\
47 / 98(48 \%)\end{array}$ \\
\hline $\begin{array}{l}\text { Complications using Clavien-Dindo } \\
\text { classification (\%) } \\
\text { (<30 days after discharge) }\end{array}$ & $\begin{array}{l}\text { Grade I: } 1 / 98(1.02 \%) \\
\text { Grade II: } 2 / 98(2.04 \%) \\
\text { Grade IIIa: 0/98 (0\%) } \\
\text { Grade IIIb: } 2 / 98(2.04 \%) \\
\text { Grade IVa: 0/98 (0\%) } \\
\text { Grade IVb: 0/98 (0\%) } \\
\text { Grade V: 0/98 (0\%) }\end{array}$ \\
\hline Cause of reintervention (\%) & $\begin{array}{l}\text { Overall reintervention rate: } \\
21 / 98(21.4 \%) \\
\text { GERD/Biliary reflux 14/21 } \\
(66.6 \%)^{2} \\
\text { Internal Hernia } 4 / 21(19 \%) \\
\text { Incisional hernia } 2 / 21(9.5 \%) \\
\text { Cholelitiasis } 1 / 21(4.8 \%)\end{array}$ \\
\hline $\begin{array}{l}\text { Resolutive reintervention for persistent } \\
\text { GERD/Biliary Reflux (\%) }\end{array}$ & $\begin{array}{l}\text { Performing Braun } \\
\text { anastomosis } 3 / 14(21.5 \%) \\
\text { Conversion to RYGB 10/14 } \\
(71.5 \%) \\
\text { Hiatoplasty } 1 / 14(7 \%) \\
\end{array}$ \\
\hline $\begin{array}{l}\text { Overall reintervention rate for type of OAGB } \\
(\%)\end{array}$ & $\begin{array}{l}\text { Without Braun anastomosis } \\
11 / 51(21.6 \%) \\
\text { With Braun anastomosis } \\
10 / 47(21.3 \%)\end{array}$ \\
\hline Mean Hospitalization Time \pm SD & $4.8 \pm 3.8$ \\
\hline${ }^{3}$ Resolution of comorbidities (\%) & $\begin{array}{l}\text { GERD } 20 / 20(100 \%) \\
\text { OSAS } 9 / 10(90 \%) \\
\text { Hypertension } 17 / 20(85 \%) \\
\text { Diabetes Mellitus 5/7 } \\
(71.4 \%)\end{array}$ \\
\hline
\end{tabular}

This table reports data from patients after the OAGB surgery.

$\%$ EBMIL $=\%$ Excess Body Mass Index Lost

'Values at 1 year follow-up (115/118 patients)

${ }^{2} 12$ cases were non complicated GERD/Biliary Reflux, 2 cases were complicated by Anastomotic Ulcer

${ }^{3}$ Rates are referred to latest follow up

- Grade II: 2/98 (2.04\%). One postoperative blood loss required blood transfusion; one patient with incidental finding of Diphillobotrium Latum (fish tapeworm) colonizing the bowel that required specific therapy before discharge.

- Grade IIIb: 2/98 (2.04\%). Two cases of anastomotic ulcer that required revisional surgery. In one case, there was an anastomotic perforation. Both patients developed this complications $<30$ days after discharge and were treated performing Braun anastomosis. No intraoperative complications or conversion to laparotomy were reported.

\section{Follow-up}

Mean follow-up was $27 \pm 13$ months. One year follow-up was completed in 90 of 98 patients. In patients with weight regain and starting BMI $>35 \mathrm{~kg} / \mathrm{m}^{2}$ (54/98) the Excess Body Mass Index Lost (\%EBMIL) was $52 \pm 30 \%$ after OAGB surgery. Late complications ( $>30$ days after discharge) requiring new surgery were found in 19 patients (Table 3). There were 2 cases ( $<30$ days after discharge) with the persistence of severe GERD after OAGB which complicated with anastomotic ulcer requiring urgent revision surgery. Overall, 21 patients required reintervention (21/98; $21.4 \%)$ after discharge. The main cause of revisional surgery was severe GERD/Biliary Reflux $(14 / 21 ; 66.6 \%)$ and bowel obstruction due to internal hernia $(4 / 21 ; 19 \%)$. The overall rate of internal hernia in our experience was $4 \%$ (4/98). No statistically significant difference $(p=0.83)$ was found in reintervention rates between patients underwent OAGB without Braun anastomosis $(11 / 51 ; 21.6 \%)$ and OAGB with Braun anastomosis $(10 / 47 ; 21.3 \%)$. In 20 patients with initial severe GERD after Sleeve Gastrectomy (17\%), a reintervention after OAGB was needed on 14 cases $(70 \%)$ due to the persistence of GERD or development of biliary reflux. In this case, a LRYGB was successfully performed to resolve symptoms (see Table 3). The impact of OAGB with Braun anastomosis on GERD/Biliary reflux was also evaluated (see Table 4 ). No statistically significant difference $(p=0.70)$ was found in reintervention rates for GERD/ Biliary reflux between OAGB and OAGB with Braun anastomosis groups. A second reintervention to LRYGB was necessary in $50 \%$ of patients that underwent non-modified OAGB as the first surgery. 
Table 4. OAGB vs OAGB with Braun anastomosis for the treatment of GERD/Biliary reflux

\begin{tabular}{lll}
\hline Type of revisional surgery & OAGB & OAGB + Braun anastomosis \\
\hline $\begin{array}{l}\text { Number of patients underwent reintervention } \\
\text { for GERD/Biliary Reflux (\%) }\end{array}$ & $8 / 14(57.14 \%)$ & $6 / 14(42.85 \%)$ \\
\hline First reintervention (cases) & & \\
& Braun anastomosis $(7 / 8)$ & RYGB $(5 / 6)$ \\
& RYGB $(1 / 8)$ & Hiatoplasty $(1 / 6)$ \\
\hline Second reintervention (cases) & RYGB (4/7) & - \\
\hline Resolutive intervention (cases, \%) & RYGB $(5 / 8,62.5 \%)$ & RYGB $(5 / 6,83.3 \%)$ \\
& Braun anastomosis $(3 / 8.37 .5 \%)$ & Hiatoplasty $(1 / 616.7 \%)$ \\
\hline $\begin{array}{l}\text { This table reports differences between OAGB vs OAGB + Braun treatment for patients incurred in GERD/Biliary reflux after revisional } \\
\text { OAGB surgery }\end{array}$ &
\end{tabular}

\section{Internal Hernia}

The first patient was a 49 year-old female who underwent laparoscopic gastric plication in 2017 for morbid obesity associated with arterial hypertension (BMI $35.1 \mathrm{~kg} / \mathrm{m}^{2}$ ). A Dor fundoplication was sub-sequently carried out in 2018 for developing severe GERD symptoms. Both surgeries were carried out in another center. Due to the persistence of severe GERD, the patient was admitted in our hospital where she underwent laparoscopic OAGB with Braun anastomosis in January 2019 (BMI $20.4 \mathrm{~kg} / \mathrm{m}^{2}$ ). The patient was discharged on the third postoperative day without any complication. Three months later, the patient presented in our emergency department for intermittent abdominal pain, nausea, vomiting and bowel obstruction (BMI $16.4 \mathrm{~kg} / \mathrm{m}^{2}$ ). These intermittent symptoms started 1 month after the OAGB procedure and were attributed to an incisional hernia. A CT scan was performed and described a "whirl sign" (Fig. 1), suggesting a herniation below the Treitz ligament, on the left side. Surgery confirmed an internal hernia through the Petersen defect. Braun's anastomosis was not involved. The closure of the mesenteric defect was not carried out to avoid any damage due to tissues being frail and the defect was reported to be small. The patient was discharged on the fifth postoperative day without any complications. Two months later, in June 2020, the patient presented again in our emergency department for the same symptoms. The patient underwent further laparoscopic revision surgery that showed a recurrence of internal hernia thought the
Petersen defect. Braun's anastomosis was involved in the herniation process through the Petersen defect and was found to be revolved. A closure of the mesenteric defect and a new Braun's anastomosis distal to previous one was performed. Sixth months later, the patient underwent LRYGB conversion for GERD/biliary reflux. The follow up was carried out with no further complications.

The second patient was a 39-year-old female who underwent different bariatric procedures (sleeve gastrectomy in 2013 and re-sleeve gastrectomy in 2015) for severe morbid obesity (BMI $45.4 \mathrm{~kg} / \mathrm{m}^{2}$ ) with weight regain after the first surgery. The laparoscopic OAGB was performed in March 2019 for developing severe GERD symptoms after the second sleeve gastrectomy (BMI $32.6 \mathrm{~kg} / \mathrm{m}^{2}$ ). The patient was discharged on the fourth postoperative day without any complications. Seven months later, the patient was admitted to another hospital emergency department for severe intermittent abdominal pain with

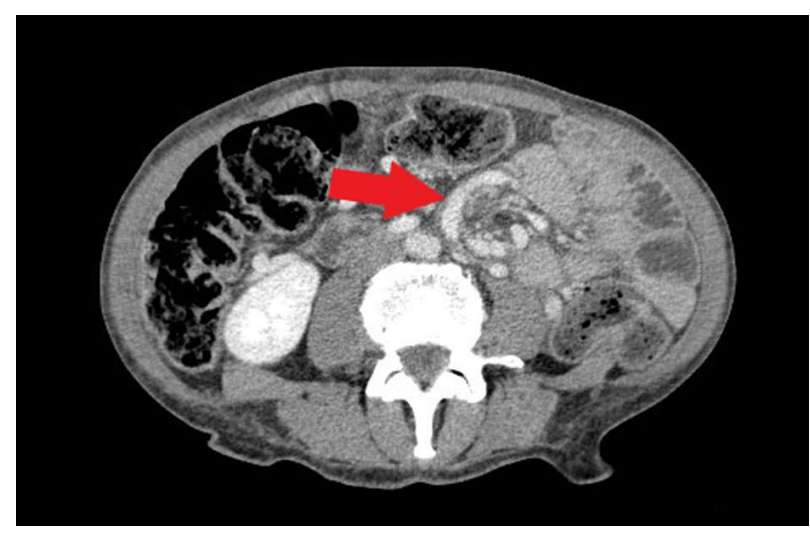

Figure 1. A CT scan image of patient $n 1$. The arrow points to the "whirl sign" 
vomiting. These symptoms started 4 months after the OAGB procedure. The patient underwent a CT abdomen scan that showed bowel air-fluid levels and free fluid in the abdomen with no other pathological signs. The patient was treated conservatively and bowel obstruction symptoms resolved. One month later (November 2019), the patient was admitted to our surgical department for SBO symptoms. An urgent $\mathrm{CT}$ abdomen scan was performed showing a "mesenteric swirl" (Fig. 2): the surgery confirmed the presence of internal herniation trough Petersen defect with bowel ischemia but no signs of infarction. A closure of mesenteric defect was performed. The patient was discharged on the fourth postoperative day without any complications. The follow-up was carried out with no further complications.

The third patient was a 33-year-old female who underwent sleeve gastrectomy in September 2019 for morbid obesity (BMI 43.3 $\mathrm{kg} / \mathrm{m}^{2}$ ). Severe GERD occurred one month after the procedure and it was treated with laparoscopic OAGB and hiatoplasty in October $2019\left(\mathrm{BMI} 31.6 \mathrm{~kg} / \mathrm{m}^{2}\right)$. The patient was discharged on the third postoperative day without any complications. Three months after surgery, the patient was admitted to our emergency department for biliary colic, abdominal pain and vomiting starting few weeks before. A gastrointestinal transit evaluation, made with X-ray exam after Gastrografin swallow, showed no pathological signs. The patient underwent surgery for

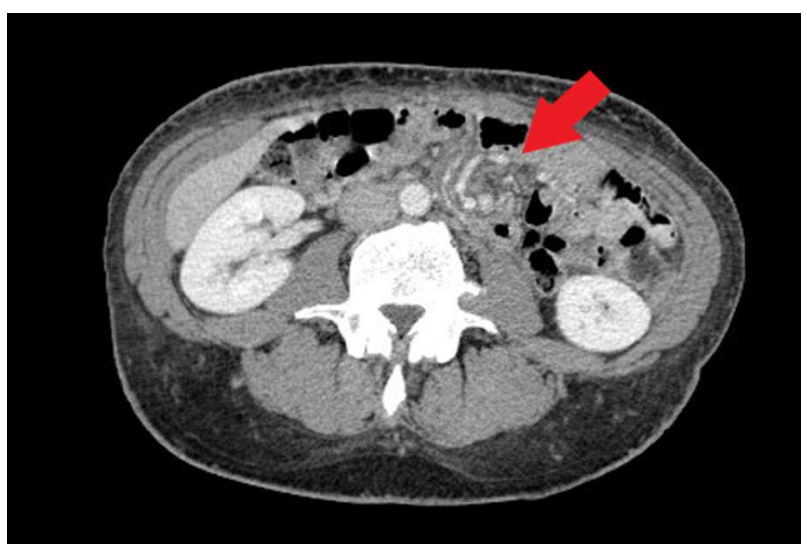

Figure 2. A CT scan image of patient $n 2$. The arrow points to the "whirl sign"
OAGB revision and laparoscopic cholecystectomy: during surgery, an internal hernia was discovered and a closure of the mesenteric Petersen defect was carried out. The patient was discharged on the fourth postoperative day. Eleven months later, the patient underwent LRYGB conversion for severe GERD. The follow-up was carried out with no further complications.

The fourth patient was a 50-year-old female who underwent laparoscopic sleeve gastrectomy in June 2016 (BMI $37.2 \mathrm{~kg} / \mathrm{m}^{2}$ ) for morbid obesity associated with arterial hypertension. Few months after surgery, the patient developed severe GERD, which was partially controlled with proton pump inhibitor. In January 2020, the patient was admitted to our hospital for increased GERD symptoms despite pharmacological therapy. The patient underwent OAGB with Braun anastomosis surgery. Four months later, the patient was admitted to another hospital emergency department for abdominal pain and vomiting, starting few weeks before. A CT scan was performed revealing air-fluid levels in the small bowel and a conservative therapy with rehydration was administered. The patient was transferred to our hospital where a second CT abdomen scan was performed, revealing no pathological signs. Three days after admission, due to the persistence of intermittent abdominal pain, nausea and vomiting, the patient underwent a third CT scan with oral administration of Gastrografin. This exam revealed a stop at Braun anastomosis in contrast progression and caused vomiting in the patient. Consequently, the patient underwent revision surgery. The surgery confirmed an intestinal herniation through a mesenteric defect below the Braun anastomosis. The internal hernia was reduced and the mesenteric defect was closed. The follow-up showed no further complications.

\section{Discussion}

OAGB is considered a safe and effective procedure to treat obese patients according to the 2020 OGB/MGB IFSO consensus study 
but there is still a lack of studies about OAGB as revisional surgery for morbid obesity. Our experience with revisional OAGB consists of 98 procedures in a six-year period. The main surgery to treat morbid obesity in our center is LSG, which was the first bariatric procedure in $96 \%$ of patients that underwent revisional OAGB. While we experienced low complication rate during hospitalization (see Table 3), we also found an overall reintervention rate of $21.4 \%$ in our series. The main cause of reintervention was persistence or development of severe GERD/biliary reflux which was treated performing Braun anastomosis or LRYGB (20-21). The presence of Braun anastomosis did not increase complication rate as there was no statistically significant difference in reintervention rate between patients that underwent OAGB with Braun anastomosis and the ones without Braun anastomosis. However, OAGB with Braun anastomosis did not prove to be effective for the treatment of GERD/Biliary reflux in our series, since $50 \%$ of patients underwent a second revisional surgery to LRYGB (see Table 4). The overall reintervention rate was higher than the one reported in literature (2-10\%) for OAGB as primary surgery (22-24). This could suggest OAGB as secondary surgery should not be considered to treat patients with morbid obesity and GERD symptoms due to high reintervention chance. However, two systematic reviews were published recently, suggesting that revisional OAGB is a safe and feasible procedure (25-26). This topic is still controversial in literature; studies available on the matter are not randomized, suffer in patient heterogeneity and lack of a standardized OAGB procedure. For example, in previous cited systematic reviews, the biliopancreatic limb mean length reported is $200 \mathrm{~cm}(150-350 \mathrm{~cm})$, while in our procedure it is $150 \mathrm{~cm}$.

In our experience, the second most common cause of reintervention (19\%) after OAGB was $\mathrm{IH}$, which was found in $4 \%(4 / 98)$ of patients. OAGB is reported to have low chance $(<1 \%)$ of developing internal hernia compared to LRYGB (27). Even recent systematic reviews about revisional OAGB reported absent or minimal rate of bowel obstruction as complication (25-26). However, starting from 2015, different authors reported novel cases of IH after OAGB procedures. To this date, considering the cases reported in this paper, there are 9 published cases in literature of $\mathrm{IH}$ following OAGB and few more that are not published (10,14-18). All IH cases reported in literature have similar clinical presentation with intermittent abdominal pain, nausea, vomiting and an evolution to overt SBO. The spontaneous reduction of internal hernia and subsequent intermittent pain, along with nonspecific associated symptoms, make the early diagnosis a challenge. Moreover, the rates of internal hernia reported in OAGB are considered negligible, causing this complication to be underestimated by surgeons. All these factors suggest that internal herniation following OAGB could be more unrecognized than absent (19). A CT scan is the first-line imaging exam to evaluate the presence of internal hernia and its complications (28). Several studies have shown that the "mesenteric swirl" sign on CT scan (Fig. 1) is the best indicator of an internal hernia following gastric bypass (29-30). While there is a clear indication for closing mesenteric defects during LRYGB to decrease the chance of developing $\mathrm{IH}$, in OAGB the consensus agreed this procedure is unnecessary. Neuberg et al. described no cases of Petersen hernia in their series of 163 patients with a follow-up of 5 to 8 years, with no closure of Petersen defect. According to them, the non-developing of $\mathrm{IH}$ is likely due to the absence of mesenteric dissection in the OAGB (22). Similar outcomes are reported in other large series for OAGB with mid-term follow-up $(11,23)$. However, as first reports of IH are being published, it should be questioned whether this approach should be reconsidered $(15,19)$. It should be considered that even for LRYGB there was no recommendation for routinely closure of mesenteric defects until surgeons became aware of the high incidence of internal hernia several years after the first procedures (31-34). The diagnosis of IH in early LRYGB procedures 
was underestimated because in open surgery for RYGB the internal hernia complication was extremely rare. It was only recently that randomized trials demonstrated definitively that closing the mesenteric defects greatly reduces IH occurrence (35). Closing the mesenteric defects in OAGB is a controversial topic in literature. Most authors do not recommend the systematic closing of the defects because the IH after OAGB is extremely rare and it could lead to severe early complications like the kinking of jejuno-jejunostomy, which is also described in a recent randomized controlled trial of Stenberg et al. (10,33). For these authors, the longer gastric pouch and a wide Petersen space could eventually decrease the incidence of internal hernia. However, some authors have argued that leaving open defects could increase the chances of whole bowel infarction in the occurrence of internal herniation. This is due to the whole bowel herniation that may swirl mesenteric vascular peduncle and subsequent massive infarction (36). Some authors reported that rapid excess weight loss (rEWL\%) in patients that underwent bariatric surgery could lead to the development of internal hernia (37-39). Schneider et al. reported 58 cases of internal hernia following LRYGB. Almost half of these patients $(46.5 \%)$ had periods of $r E W L \%$, which is defined as a loss greater than the 90th percentile of expected weight loss. Loss in body weight is reported to be alone a risk factor for developing internal herniation after LRYGB due to the decrease of visceral fat that could widen the space left open by mesenteric dissection (40-41). In our series, all patients with IH underwent a significant weight loss, ranging from $7 \%$ to $28 \%$ from pre-OAGB procedure weight, even if their BMI was normal or overweight $\left(\mathrm{BMI}<30 \mathrm{~kg} / \mathrm{m}^{2}\right)$. It is unclear if the recurrent SBO symptoms, with abdominal pain and vomiting, could have been the reason for a reduction of caloric intake leading the weight loss or if the weight loss due to OAGB could have led to SBO due to initial internal herniation. However, in our experience, all patients after OAGB surgery underwent significant weight loss, but only $4 \%$ developed internal hernia. Despite the low rates of $\mathrm{IH}$ reported in the literature, it is clear to us that the intermittent nonspecific symptoms may greatly delay the diagnosis, especially if the complication rate is underestimated. The natural evolution of IH is a SBO that could lead to bowel ischemia and subsequent bowel infarction with the need of an emergency surgical revision with the closure of all mesenteric defects. This is why IH should always be considered and investigated with abdominal CT scan ("whirl sign") in patients with persistence of abdominal nonspecific symptoms that underwent OAGB. The closure of mesenteric defects should be carried out always during revisional surgery for IH to avoid any recurrence of internal herniation. Further studies with larger patient populations are needed to evaluate the real incidence of internal hernia and only randomized controlled trials could set between routinely closing or not the mesenteric defects in the OAGB surgery to avoid this late complication.

\section{Conclusion}

Revisional OAGB surgery showed a higher incidence rate of late complications, and it was not the best option to treat GERD in morbidly obese patients. The main cause of reintervention in our experience was the development/ persistence of severe GERD/biliary reflux and internal herniation. Overall, $4 \%$ of patients following laparoscopic revisional OAGB developed bowel obstruction due to internal hernia and required urgent revisional surgery. Since there are no randomized studies on the matter, it is unclear if routine closure of mesenteric defects should be carried out, even if it should always be considered by surgeons. Moreover, we do stress the need to consider this complication more frequent than it is reported in literature.

\section{Funding}

No Funding was received. 


\section{Conflicts of Interest/Competing Interests}

The authors declare that they have no conflicts of interest.

\section{Availability of Data and Material}

\section{Not applicable.}

\section{Code Availability}

Not applicable.

\section{References}

1. Ramos AC, Chevallier JM, Mahawar K, Brown W, Kow L, White KP, et al. FSO (International Federation for Surgery of Obesity and Metabolic Disorders) Consensus Conference Statement on One-Anastomosis Gastric Bypass (OAGB-MGB): Results of a Modified Delphi Study. Obes Surg. 2020; 30(5):1625:1634.

2. Magouliotis DE, Tasiopoulou VS, Tzovaras G. One Anastomosis Gastric Bypass Versus Roux-en-Y Gastric Bypass for Morbid Obesity: an Updated Meta-Analysis. Obes Surg. 2019;29(9):2721-2730.

3. Elms L, Moon RC, Varnadore S, Teixeira AF, Jawad MA. Causes of small bowel obstruction after Roux-en-Y gastric bypass: a review of 2,395 cases at a single institution. Surg Endosc. 2014;28(5):1624-1628.

4. Nguyen NT, Goldman C, Rosenquist CJ, Arango A, Cole CJ, Lee SJ, et al. Laparoscopic versus open gastric bypass: a randomized study of outcomes, quality of life, and costs. Ann Surg. 2001;234(3):279-89; discussion 289-91.

5. Higa KD, Boone KB, Ho T. Complications of the laparoscopic Roux-en-Y gastric bypass: 1,040 patients--what have we learned? Obes Surg. 2000; 10(6):509-13

6. Peterli R, Wölnerhanssen BK, Vetter D, Nett P, Gass M, Borbély Y, et al. Laparoscopic Sleeve Gastrectomy Versus Roux-Y-Gastric Bypass for Morbid Obesity-3-Year Outcomes of the Prospective Randomized Swiss Multicenter Bypass Or Sleeve Study (SM-BOSS). Ann Surg. 2017; 265(3):466-473.

7. Faria G, Preto J, Oliveira M, Pimenta T, Baptista M, Costa-Maia J. Petersen's space hernia: A rare but expanding diagnosis. Int J Surg Case Rep. 2011; 2(6):141-3.

8. Baba A, Yamazoe S, Dogru M, Okuyama Y, Mogami T, Kobashi Y, et al. Petersen hernia after open gastrectomy with Roux-en-Y reconstruction: a report of two cases and literature review. Springerplus. 2015 Dec 2;4:753.

9. Kang KM, Cho YS, Min SH, Lee Y, Park KB, Park YS, et al. Internal hernia after gastrectomy for gastric cancer in minimally invasive surgery era. Gastric Cancer. 2019;22(5):1009-1015.

10. Kular KS, Prasad A, Ramana B, Baig S, Mahir Ozmen M, Valeti M, et al. Petersen's hernia after mini (one anastomosis) gastric bypass. J Visc Surg. 2016;153(4):321.

11. Musella M, Susa A, Greco F, De Luca M, Manno E, Di Stefano C, et al. The laparoscopic mini-gastric bypass: the Italian experience: outcomes from 974 consecutive cases in a multicenter review. Surg Endosc. 2014;28(1): 156-63. Epub 2013 Aug 28.

12. Lee WJ, Ser KH, Lee YC, Tsou JJ, Chen SC, Chen JC. Laparoscopic Rouxen-Y vs. mini-gastric bypass for the treatment of morbid obesity: a 10-year experience. Obes Surg. 2012;22(12):1827-34.

13. Kular KS, Prasad A, Ramana B, Baig S, Mahir Ozmen M, Valeti M, et al. Petersen's hernia after mini (one anastomosis) gastric bypass. J Visc Surg.
2016;153(4):321.

14. Genser L, Carandina S, Soprani A. Petersen's internal hernia complicating a laparoscopic omega loop gastric bypass. Surg Obes Relat Dis. 2015; 11(5):e33-4

15. Facchiano $E$, lannelli $A$, Lucchese $M$. Internal hernia after mini-gastric bypass: Myth or reality? J Visc Surg. 2016;153(3):231-2.

16. Abbas A, Kermansaravi M, Eghbali F, Pazouki A. Another Petersen's Space Hernia After One Anastomosis Gastric Bypass: a Video Case Report. Obes Surg. 2019;29(11):3776-3777.

17. Kermansaravi M, Kazazi M, Pazouki A. Petersen's Space Internal Hernia after Laparoscopic One Anastomosis (Mini) Gastric Bypass. Case Rep Surg. 2018;2018:9576120.

18. AlZarooni N, Abou Hussein B, Al Marzouqi O, Khammas A. Gastric Remnant Perforation Caused by Peterson's Hernia Following One Anastomosis Gastric Bypass: a Rare Complication. Obes Surg. 2020;30(8):3229-3232.

19. Mahawar KK. Petersen's Hernia may be Commoner After OAGB/MGB Than Previously Reported. Obes Surg. 2018;28(1):257-258.

20. Olmi S, Oldani A, Cesana G, Ciccarese F, Uccelli M, De Carli SM, et al. Laparoscopic One Anastomosis Gastric Bypass Versus Laparoscopic One Anastomosis Gastric Bypass with Braun Anastomosis: What's Better? J Laparoendosc Adv Surg Tech A. 2019;29(11):1469-1474.

21. Musella M, Susa A, Manno E, De Luca M, Greco F, Raffaelli M, et al. Complications Following the Mini/One Anastomosis Gastric Bypass (MGB/OAGB): a Multi-institutional Survey on 2678 Patients with a Mid-term (5 Years) Follow-up. Obes Surg. 2017;27(11):2956-2967.

22. Hussain A, Van den Bossche M, Kerrigan DD, Alhamdani A, Parmar C, Javed $S$, et al. Retrospective cohort study of 925 OAGB procedures. The UK MGB/OAGB collaborative group. Int J Surg. 2019;69:13-18.

23. Neuberg M, Blanchet MC, Gignoux B, Frering V. Long-Term Outcomes After One-Anastomosis Gastric Bypass (OAGB) in Morbidly Obese Patients. Obes Surg. 2020;30(4):1379-1384.

24. Musella M, Susa A, Manno E, De Luca M, Greco F, Raffaelli M, et al. Complications Following the Mini/One Anastomosis Gastric Bypass (MGB/OAGB): a Multi-institutional Survey on 2678 Patients with a Mid-term (5 Years) Follow-up. Obes Surg. 2017;27(11):2956-2967.

25. Parmar CD, Gan J, Stier C, Dong Z, Chiappetta S, El-Kadre L, et al. One Anastomosis/Mini Gastric Bypass (OAGB-MGB) as revisional bariatric surgery after failed primary adjustable gastric band (LAGB) and sleeve gastrectomy (SG): A systematic review of 1075 patients. Int J Surg. 2020; 81:32-38.

26. Kermansaravi M, Shahmiri SS, DavarpanahJazi AH, Valizadeh R, Berardi G, Vitiello A, et al. One Anastomosis/Mini-Gastric Bypass (OAGB/MGB) as Revisional Surgery Following Primary Restrictive Bariatric Procedures: a Systematic Review and Meta-Analysis. Obes Surg. 2021;31(1):370-383. Epub 2020 Oct 28.

27. Deitel M, Rutledge R. Mini-gastric bypass: Prevention and management of complications in performance and follow-up. Int J Surg. 2019;71:119-123.

28. Doishita S, Takeshita T, Uchima Y, Kawasaki M, Shimono T, Yamashita A, et al. Internal Hernias in the Era of Multidetector CT: Correlation of Imaging and Surgical Findings. Radiographics. 2016;36(1):88-106.

29. Iannuccilli JD, Grand D, Murphy BL, Evangelista P, Roye GD, Mayo-Smith W. Sensitivity and specificity of eight CT signs in the preoperative diagnosis of internal mesenteric hernia following Roux-en-Y gastric bypass surgery. Clin Radiol. 2009;64(4):373-80.

30. Lockhart ME, Tessler FN, Canon CL, Smith JK, Larrison MC, Fineberg NS, et al. Internal hernia after gastric bypass: sensitivity and specificity of seven CT signs with surgical correlation and controls. AJR Am J Roentgenol. 2007;188(3):745-50.

31. Higa KD, Ho T, Boone KB. Internal hernias after laparoscopic Roux-en-Y gastric bypass: incidence, treatment and prevention. Obes Surg. 2003;13(3): 350-4.

32. Champion JK, Williams M. Small bowel obstruction and internal hernias after laparoscopic Roux-en-Y gastric bypass. Obes Surg. 2003;13(4):596-600.

33. Filip JE, Mattar SG, Bowers SP, Smith CD. Internal hernia formation after 
laparoscopic Roux-en-Y gastric bypass for morbid obesity. Am Surg. 2002;68(7):640-3.

34. Cho M, Pinto D, Carrodeguas L, Lascano C, Soto F, Whipple 0, et al. Frequency and management of internal hernias after laparoscopic antecolic antegastric RouX-en-Y gastric bypass without division of the small bowel mesentery or closure of mesenteric defects: review of 1400 consecutive cases. Surg Obes Relat Dis. 2006;2(2):87-91.

35. Stenberg E, Szabo E, Tgren G, Ottosson J, Marsk R, Lönroth H, et al. Closure of mesenteric defects in laparoscopic gastric bypass: a multicentre, randomised, parallel, open-label trial. Lancet. 2016;387(10026):1397-1404.

36. Facchiano E, lannelli A, Lucchese M. Reply to letter to the editor "Petersen's Hernia after mini (one anastomosis) gastric bypass". J Visc Surg. 2016; 153(4):323.

37. Miyagaki H, Takiguchi S, Kurokawa Y, Hirao M, Tamura S, Nishida T, et al.
Recent trend of internal hernia occurrence after gastrectomy for gastric cancer. World J Surg. 2012;36(4):851-7.

38. Kojima K, Inokuchi M, Kato K, Motoyama K, Sugihara K. Petersen's hernia after laparoscopic distal gastrectomy with Roux-en-Y reconstruction for gastric cancer. Gastric Cancer. 2014;17(1):146-51.

39. Schneider C, Cobb W, Scott J, Carbonell A, Myers K, Bour E. Rapid excess weight loss following laparoscopic gastric bypass leads to increased risk of internal hernia. Surg Endosc. 2011;25(5):1594-8. Epub 2010 Nov 12.

40. Ahmed AR, Rickards G, Husain S, Johnson J, Boss T, O'Malley W. Trends in internal hernia incidence after laparoscopic Roux-en-Y gastric bypass. Obes Surg. 2007;17(12):1563-6.

41. Hope WW, Sing RF, Chen AY, Lincourt AE, Gersin KS, Kuwada TS, et al. Failure of mesenteric defect closure after Roux-en-Y gastric bypass. JSLS. 2010;14(2):213-6. 